\title{
Enhancing Thai EFL Students' EFL Vocabulary Knowledge through the Use of Task-Based Language Teaching and Storytelling Technique Adopting Thai Folktales
}

\author{
Khomkrit Tachom \\ School of Liberal Arts, University of Phayao, Thailand. \\ Email:ktachom@gmail.com
}

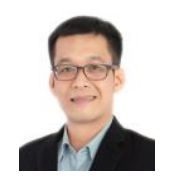

\begin{abstract}
This study aimed to examine the development of EFL students' vocabulary knowledge adopting a task-based method with 32 Thai students who enrolled in an English for Communication course at a university in northern Thailand. This study emphasized improving the Thai EFL students' English vocabulary knowledge by requiring students to retell six Thai folktales in English translation to their group members. The pretest-posttest design, as well as an interview, were employed to indicate the students' vocabulary improvement after retelling Thai folktales. The findings showed that the students' post-test scores were statistically higher than their pre-test scores, and the students felt that the folktale tasks helped them enhance their vocabulary knowledge. The results of this study indicate that the students learned English vocabulary in an engaging and meaningful way through storytelling; therefore, the students' vocabulary retention is likely high.
\end{abstract}

Keywords: EFL vocabulary, Task-based language teaching, Folktale, Task, Vocabulary knowledge, Storytelling technique.

Citation | Khomkrit Tachom (2021). Enhancing Thai EFL Students' EFL Vocabulary Knowledge through the Use of TaskBased Language Teaching and Storytelling Technique Adopting Thai Folktales. Asian Journal of Education and Training, 7(4): 235243. History:

Received: 1 September 2021

Revised: 6 October 2021

Accepted: 28 October 2021

Published: 22 November 2021

Licensed: This work is licensed under a Creative Commons

Attribution 3.0 License $($ (c) E)

Publisher: Asian Online Journal Publishing Group
Funding: The Unit of Excellence at the University of Phayao provided funding for this research project.

Competing Interests: The author declares that there are no conflicts of interests regarding the publication of this paper.

Transparency: The author confirms that the manuscript is an honest, accurate, and transparent account of the study was reported; that no vital features of the study have been omitted; and that any discrepancies from the study as planned have been explained.

Ethical: This study follows all ethical practices during writing.

\section{Contents}

1. Introduction

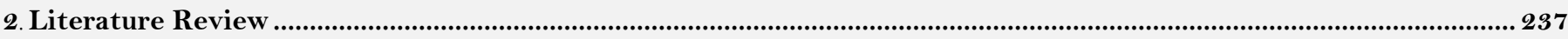

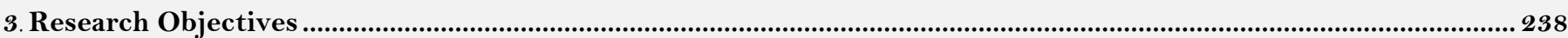

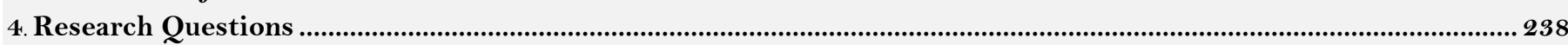

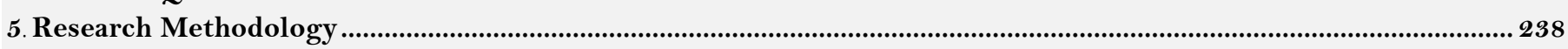

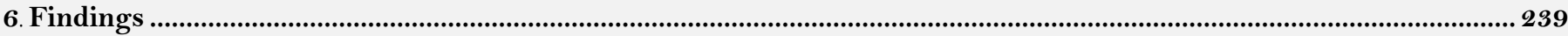

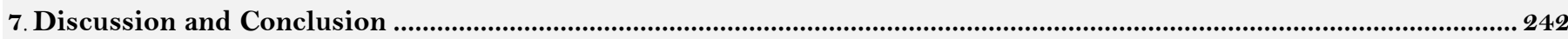

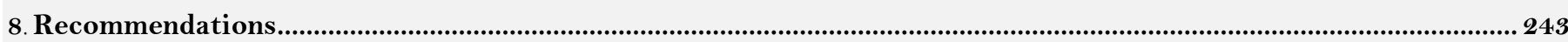

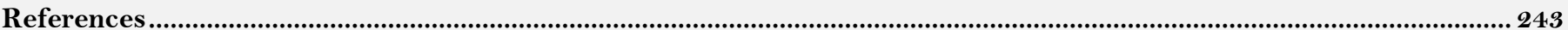




\section{Contribution of this paper to the literature}

This study contributes to existing literature by examining the development of EFL students' vocabulary knowledge adopting a task-based method with 32 Thai students who enrolled in English for Communication course at a university in northern Thailand.

\section{Introduction}

Vocabulary knowledge is the foundation for communication, and it is essential in both receptive and productive communication. Language users who know more vocabulary are better able to comprehend both written and spoken messages, as well as leads to more successful communication overall. Possessing lexical repertoire enables language learners to enhance their developing knowledge of the language while also applying their knowledge to daily conversation. When studying a foreign language, learners should get familiar with and practice using the vocabulary of a certain language, as vocabulary is essential for developing language abilities in competent language users. Thai students who study English as a compulsory subject from elementary school through higher education are expected to be able to learn and utilize English effectively once they have completed their education. Despite learning English for almost 10 years, from kindergarten to primary school, most Thai students still have difficulty speaking in English with their classmates or even foreigners. The causes of communication difficulties might be due to many different factors. Limited vocabulary knowledge, in particular, has a substantial influence on learners' development of language abilities such as listening, speaking, reading, and writing. Furthermore, Khamprated (2012) stated that students' insufficient grammar and vocabulary abilities might make it difficult for them to understand spoken English; as a result, students get apprehensive and concerned while attempting to communicate in English in a certain context. This phenomenon is reported in several studies that having limited vocabulary appears to be a major cause of students' communication difficulties in the classroom and outside it.

\subsection{Statement of the Problem}

Students majoring in Thai at the School of Liberal Arts, the University of Northeastern Thailand (hereinafter, UNT), have encountered a number of difficulties in communicating in English. In particular, their vocabulary knowledge for writing or speaking English is notably limited.

Many students reported that they lacked the confidence to communicate in English. This might be owing to a lack of lexical resources. Several studies also reveal that many Thai students do not generally comprehend English in both spoken and written messages due to a lack of vocabulary knowledge. According to Bualuang, Sinprajakphol, and Chanphorm (2012) the most major challenge of foreign language learners at all levels of education is a lack of lexical knowledge. Regarding EFL students at UNT, some studies reveal that, for example, the students' evaluation of English language learning outcomes was low (Sriwichai, 2014). To develop their English vocabulary knowledge, a task-based approach using storytelling can facilitate students' English vocabulary development and communication skills. To date, Task-Based Language Teaching (TBLT) has been widely used to develop various language skills for English language learners in different countries (Hamzeh, 2016; Sarani \& Sahebi, 2012; Tang, Chiou, \& Jarsaillon, 2015; Yegani \& Jodaei, 2017). The learners' language skills have been developed through some aspects of TBLT. However, recently there has been an increase in research into projectbased learning in English language teaching and learning (Alotaibi, 2020; Bakar, Noordin, \& Razali, 2019; Deveci, 2018; Liu, 2016; Sirisrimangkorn, 2018). Several studies confirm that English language learners improved their language skills, motivation, and positive attitudes towards learning through carrying out various projects using the English language. According to Bell (2010) Project-Based Learning (PBL) is a unique educational technique that teaches a diverse set of abilities required for success in the twenty-first century. Students control their own learning via inquiry and work together to do research and create projects that demonstrate their understanding. PBL applies tasks in several phases, a process which Nunan (2004) calls "maxi-tasks." In other words, PBL consists of a set of sequential and interconnected tasks that build up to a final project. Project-Based Learning can require substantial time and resources to complete an entire project. Thus, it is better for students with limited opportunities to engage in language tasks more frequently so that they can develop their learning more effectively. For Nation (2017) learners require two essential conditions in order to learn vocabulary. The first includes numerous interactions with words, whereas the second is concerned with the quality of mental processing of such encounters. Since the tasks within PBL are major components of a project, TBLT was adopted as the framework for the present study as TBLT allows learners to practice their language skills in a natural way. This implies that students engaged in real tasks can use their own linguistic resources to complete the tasks in a meaningful manner (Nunan, 2004; Samuda \& Bygate, 2008; Willis \& Willis, 2007).

Previous studies have shown several benefits of using TBLT with storytelling in the English language classroom. For example, Meri-Yilan (2020) found that using Task-Based Language Learning (TBLL) and Digital Storytelling (DST) in a blended learning mode improved Turkish university students' English-speaking skills. The students preferred the use of TBLL and DST to telling stories in the classroom and also perceived that TBLL and DST assisted them in improving their speaking skills. In addition, Azis and Hu (2020) found that the usage of collaborative DST-based tasks greatly enhanced students' writing skills. The students reported that the learning design could help them improve their ability with the English language, engagement, motivation, and 
interpersonal relationships. Moreover, the findings reported by Hamamorad (2018) suggest that TBLL and the storytelling style could enhance learners' communicative ability and generate an active, pleasant environment in which learners are joyfully engaged in the class. According to Willis and Willis (2007) storytelling can heighten a person's pleasure and generally improve our social experience. Storytelling may bring the same benefits to students learning a foreign language in the classroom. Some may claim that narrative works best with young learners. However, storytelling may also be effective with adult learners. The distinctions might be in the contents as well as the manner in which it is carried out (Willis \& Willis, 2007).

The researcher used Thai folktales with the participants in this study as Thai people are familiar with stories in their own language, and it is essential to cultivate the practice of storytelling in English. The ability to recount stories or tales, as well as discuss and summarize stories, promotes meaningful language engagement both within and outside of the classroom (Willis \& Willis, 2007). The participants in this research had prior knowledge of the tales, which allows them to perform the task of recounting the tales to their group members by drawing on their prior knowledge. A guiding principle of this study is that the incorporation of TBLT and Thai folktales may result in increased vocabulary knowledge among participants. It is also envisaged that the students in this study would be better able to tell stories or communicate in English. The most essential goal is for participants to learn more about their culture and help preserve it by recounting folktales. The most important purpose is for participants to learn more about their culture and to contribute to its preservation by telling folktales.

\section{Literature Review}

\subsection{Narrative Tasks}

In language instruction, narrative or storytelling tasks have been employed to generate learners' linguistic production. A narrative task, according to Kiernan (2003) is one in which learners construct a story within the principle of the task. In his view, the task belongs to the tasks in the task-based instruction. Narrative tasks can take a form of picture sequences, video or audio recordings, or written texts. Storytelling tasks are prominent in foreign language education studies because they are an effective way for prompting learners' extended oral production (Skehan, 2001). Furthermore, narrative tasks are an efficient technique for students to practice telling stories in public. Storytelling tasks are also used by EFL teachers since they are a pleasant approach for students to practice a language in a comfortable and natural setting. Wajnryb (2003) finds narrative tasks to be a natural medium for language acquisition. In summary, narrative tasks can help students improve their language skills.

\subsection{Previous Studies on the Application of Storytelling Tasks}

There have been several studies on the use of narrative tasks to improve learners' language development in various domains. Studies concentrating on improving learners' communication abilities have proven to be beneficial. For example, Kiernan (2003) utilized narrative tasks with low-level learners in a classroom project at a Japanese university to promote basic conversational storytelling abilities for engineering and architecture students with limited experience speaking English. This project's findings indicated that narrative tasks are an effective method to equip learners with skills to tell stories in conversation and develop learners' identities in the target language. By the completion of the course, the students were able to convey their own stories in English fluently. In another study, Mokhtar, Halim, and Kamarulzaman (2011) investigated the impact of storytelling on students' communication abilities and assessed the amount to which storytelling improves the communication skills of Malaysian university students with MUET Band scores of 1 and 2. The findings revealed that storytelling improved students' reading skills by allowing them to correlate meaning and emotions with words. In addition, the students expanded their vocabulary and learned how to employ certain words and phrases. Finally, Somdee and Suppasetseree (2013) eexamined the use of digital storytelling in the development of English-speaking abilities as well as students' satisfaction with digital storytelling learning. The findings indicated that students' speaking abilities improved when they practiced delivering a story using the Windows Movie Maker computer program.

The three studies mentioned above were carried out with university students to enhance their communication abilities. Kiernan (2003) research aimed to assist low-level learners. In this study, a wide range of conventional storytelling tasks were employed. Similarly, Mokhtar et al. (2011) emphasized the significance of extensive reading resources in establishing communication abilities. Participants in this study improved their reading abilities as well. In Somdee and Suppasetseree (2013) study, however, technology was used to improve the students' communication abilities through digital storytelling. According to the findings of these three studies, storytelling may be a useful method for both low-level and advanced students who want to develop their language skills

In terms of vocabulary, some research aimed to provide learners at various levels with more vocabulary knowledge. For example, with high school students, Kuntung (2007) examined how storytelling might promote vocabulary learning. The study employed Aesop's fables and was separated into three stages: pre-telling, while telling, and after-telling. The findings indicated that storytelling techniques helped enhance students' vocabulary development, with pictures, gestures, different intonation, and facial expressions being the most effective. The students believed that using storytelling techniques considerably aided them in recalling and understanding new words. In a study with high school students, Srihasarn (2010) explored whether vocabulary acquisition by storytelling is more successful than traditional techniques, as well as if participants accept and support the 
storytelling technique. This research was split into three stages. The teacher began by explaining the story and new vocabulary. The students then listened to the story, translated it, and shared their ideas. Finally, the students spelt the word and rewrote the story. It was discovered that the storytelling technique may help students acquire new words. The students also preferred the storytelling technique since it inspired them to acquire vocabulary via retelling, they were pleased with their intonations, and they like learning.

Storytelling was also used with primary school students. Phuksuetrong (2009) investigated the efficacy of employing storytelling to increase the vocabulary knowledge of low-achieving students. The findings indicated that using narrative strategies was beneficial in enhancing low-achieving students' vocabulary knowledge, increasing the quality of vocabulary acquisition, and promoting students' positive attitudes while engaging in activities. In another study, Soleimani and Akbari (2013) investigated whether storytelling may affect preschool students' English vocabulary development. The findings of this study suggested that storytelling might improve vocabulary acquisition and have a favorable impact on children's vocabulary development. Another study used storytelling with kindergarten students. For example, Abasi and Soori (2014) investigated the effectiveness of storytelling in improving English vocabulary learning among 20 children in kindergarten over 8 sessions. The findings of this study demonstrated that storytelling was beneficial in enhancing vocabulary development among kindergarten students. The recommendation is to utilize children's stories to boost second/foreign language acquisition in kindergarten and preschool students. Larger groups of participants and a longer term of intervention should be considered. The aforementioned studies show that students of all ages can benefit from storytelling, from elementary through high school. Further, the use of picture story books and picture tests might be the most appropriate method for young learners in preschool or kindergarten, as suggested by Soleimani and Akbari (2013) and Abasi and Soori (2014) studies. Finally, storytelling may also be utilized to increase students' cultural awareness. Hines (1995) research, for example, employed a story theater with dramatized stories, asking students to perform a piece of text and narrate a story. The findings indicated that storytelling may be used to connect cultural experiences, and the students encountered diverse cultures via the story. According to the findings of this study, when students are given the opportunity to dramatize and recount stories, they feel more comfortable, and an environment like this might help them strengthen their language skills.

\section{Research Objectives}

1. To examine the benefits of Task-Based Language Teaching and storytelling technique adopting Thai folktales in promoting learners' English vocabulary knowledge.

2. To explore learners' opinions towards vocabulary learning through the use of Task-Based Language Teaching and storytelling techniques adopting Thai folktales.

\section{Research Questions}

1. Do the use of Task-Based Language Teaching and storytelling techniques adopting Thai folktales have any effects on learners' vocabulary knowledge?

2. What are the learners' opinions towards vocabulary learning via the application of Task-Based Language Teaching and storytelling technique adopting Thai folktales?

\section{Research Methodology}

\subsection{Participants}

The participants in this research were 32 second-year Thai EFL students whose major field of study was Thai language. These students enrolled in an English for Communication course at UNT during the second semester of the 2020 school year. The participants were drawn through purposive sampling as the researcher was assigned to teach this group of students.

\subsection{Research Instruments}

Six Thai folktale tasks, a pre-test and post-test, and a focus-group interview were employed as research tools in this study. The tasks included six Thai folktales: 1) Kraithong (a magical crocodile), 2) Horse-faced Woman, 3) Golden Goby, 4) Twelve Sisters, 5) Honwichai-Khawi (a tiger and an ox transformed into a human being by a hermit's magic), and 6) Phikulthong (a woman whose speech transformed into gold as a blessing from a god for good deeds). The researcher used an English translation of the folktales in this study. The researcher also constructed the pre- and post-tests. The test contents were mostly based on vocabulary used in the stories that the students had read and retold to their group members.

Before selecting the stories, the researcher conducted the student needs analysis, asking the students to choose their own stories. At this stage, the students came up with the six stories mentioned above. The pre-test and posttest contents and focus group interview questions were verified by three experts to confirm their validity and reliability before implementation. The scores of Index of Item Objective Congruence (IOC) were between .05-1.00. 


\subsection{Data Collection}

As a teacher, the researcher gathered data from students enrolled in the English for Communication course. The following are the stages for data collecting.

1. The researcher performed the students' needs survey by asking them to select six Thai folktales from a list of twelve stories for language learning tasks. 1) Kraithong, 2) Horse-Faced Woman, 3) Golden Goby, 4) Twelve Sisters, 5) Honwichai-Khawi, and 6) Phikulthong were among the six Thai folktales.

2. Prior to the start of the study project, participants were requested to complete a pre-test.

3. The researcher assigned the students to six-person groups. Each group was referred to as the Expert Group (E group). The members of each group selected the leader of their group and assigned various roles to each member of the group, such as secretary, time keeper, or vocabulary finder. Members of the group were assigned to listen to parts of the stories told by the researchers. The members of the expert groups split out from the original groups to form the Information Searching Group (IS group). The students carried out the folktale tasks based on the following storytelling tasks cycle (Figure 1) adapted from Willis (1996) task framework.

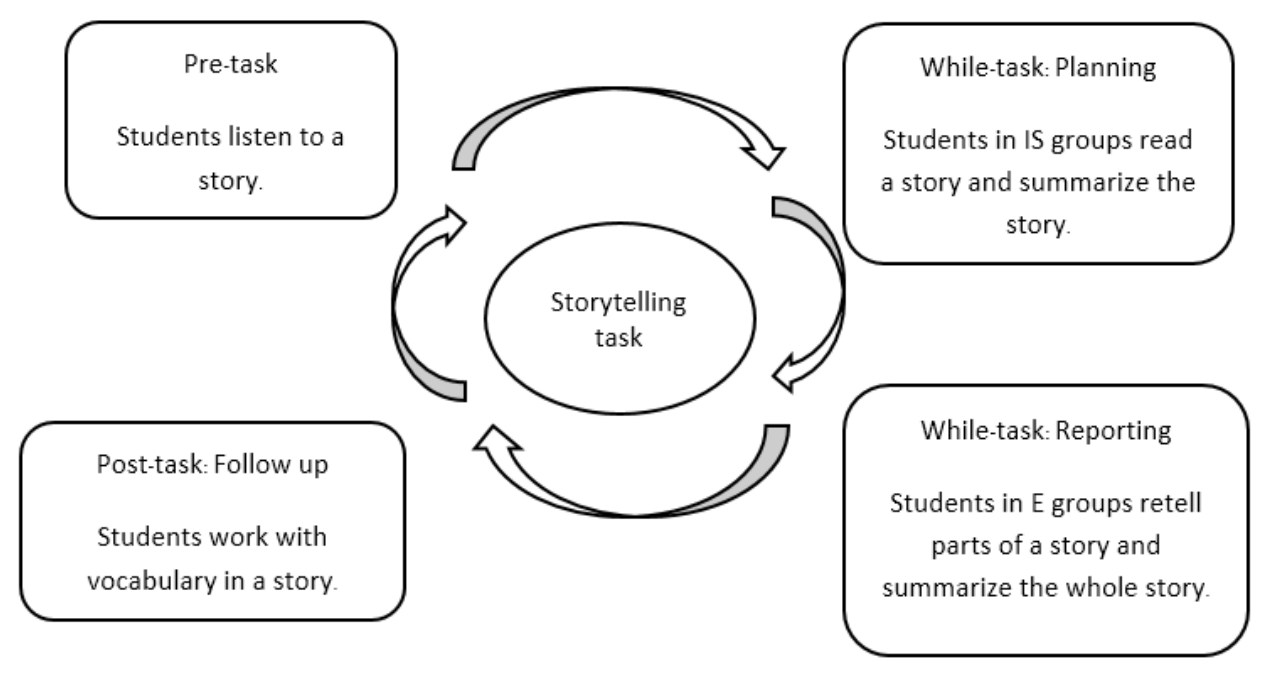

Figure-1. Task-based storytelling cycle.

4. The researcher split the stories into parts and distributed them to each IS group. Members of each IS group were required to read and summarize the different parts of the stories. In the stories, the groups had to deal with unknown vocabulary. After each IS grouping completed summarizing the stories, each member was required to return to the Expert Groups (E group) and retell the stories from beginning to end. This procedure was repeated until the study was completed. It took ten weeks to complete.

5. Following the completion of each session, participants were asked to complete session quizzes on the story's content and vocabulary.

6. Following the completion of the last session, participants were requested to complete a post-test, which was comparable to the pre-test. The focus-group interview was also carried out.

\subsection{Data Analysis}

SPSS for Windows was used to analyze the data obtained from the students' pre-test and post-test. The statistics used to analyze the data were arithmetic mean score, standard deviation, and t-test. The interview data was analyzed using content analysis. The analyzed results were then presented in a descriptive manner.

\section{Findings}

The analyzed data from the students' pre-test and post-test scores, as well as the focus-group interview, are divided into the following sections.

Table-1. Students' vocabulary pre-test and post-test scores.

\begin{tabular}{c|c|c|c|c|c}
\hline Test & $\mathbf{N}$ & $\overline{\mathbf{X}}$ & SD & t & Sig (2-tailed) \\
\hline Pre-test & 32 & 34.53 & 8.16 & 23.92 & 0.000 \\
\hline Post-test & 32 & 45.22 & 8.87 & 28.79 & 0.000 \\
\hline
\end{tabular}

\subsection{Findings from the Vocabulary Pre-Test and Post-Test Scores}

As can be seen in Table 1, the students' vocabulary pre- and post-test scores were compared. The mean scores of the post-test ( $\bar{X}=45.22$ ) were significantly higher than the pre-test ( $\bar{X}=34.53$ ) scores, suggesting that the Task-Based Language Teaching and storytelling technique helped the students to improve their English vocabulary knowledge. The results also indicate that the students were given greater opportunity to utilize language in realistic ways. They have extra time to practice the vocabulary from the stories. Furthermore, it indicates that 
group members' collaboration aided them in learning new words. Finally, it is plausible to argue that the students' prior understanding of Thai folktales aided them in making some connections between their prior knowledge and the target language. It is claimed that the learners' prior knowledge aided in the creation of new knowledge.

\subsection{Results of Focus-Group Interview}

The focus group interview was conducted after the students took the post-test. The researcher asked four questions regarding the use of Thai folktale tasks: 1) What do you think about the use of Thai folktale tasks? 2) What did you like when you participated in the project? 3) What did you learn from participating in the project? And 4) What do you want to improve or suggest? The interview data was analyzed using content analysis and the results are presented below following the themes found in each question.

\subsection{Question 1: What do you think about the use of Thai Folktale Tasks?}

The students' responses to question 1 included nine themes based on the frequency and percentage of the analysis of the students' opinions. The themes involve vocabulary, learning atmosphere, speaking, confidence, pronunciation, presentation, reading skills, usefulness and grammar. The details of each theme are shown in Table 2 below.

Table-2. Themes based on students' opinions towards the use of Thai folktale tasks.

\begin{tabular}{l|c|c}
\hline Themes & Frequency & Percentage \\
\hline 1. Vocabulary & 13 & 25.00 \\
\hline 2. Learning atmosphere & 10 & 19.23 \\
\hline 3. Speaking & 9 & 17.31 \\
\hline 4. Confidence & 6 & 11.54 \\
\hline 5. Pronunciation & 4 & 7.69 \\
\hline 6. Presentation & 3 & 5.77 \\
\hline 7. Reading skills & 3 & 5.77 \\
\hline 8. Usefulness & 3 & 5.77 \\
\hline 9. Grammar & 1 & 1.92 \\
\hline Total & 52 & 100.00 \\
\hline
\end{tabular}

Table 2 shows a total of 52 sub-themes based on the frequency of the students' opinions regarding the use of Thai folktale tasks. Regarding the highest frequency, the majority of the students felt that the use of Thai folktale tasks provided them with knowledge of vocabulary $(25.00 \%$ ), as one student from the focus group interview commented:

"I thought that I had learnt a lot about the words from the stories." (FGI1 student 1)

For the second highest frequency, most students reported that they performed the folktale tasks in a good learning atmosphere (19.23\%). One student commented:

"I had a lot of fun and was excited to tell stories." (FGI 1 student 4)

The third place of the frequency of the students' responses was the speaking. Most students commented that they had gained more opportunities to speak (17.31\%) the target language through retelling Thai folktales to their group members, as one student reported:

"I had got speaking skills." (FGI1 student 5)

With regard to the lowest frequency, few students felt that the grammar (1.92\%) was the area which they dealt with the least.

Table-3. Students' preferences for participating in the project

\begin{tabular}{l|c|c}
\hline Themes & Frequency & Percentage \\
\hline 1. Atmosphere & 6 & 19.35 \\
\hline 2. Group work & 5 & 16.13 \\
\hline 3. Speaking & 5 & 16.13 \\
\hline 4. Vocabulary & 3 & 9.68 \\
\hline 5. Interaction & 3 & 9.68 \\
\hline 6. Pronunciation & 3 & 9.68 \\
\hline 7. Rehearsal & 3 & 9.68 \\
\hline 8. Test & 2 & 6.45 \\
\hline 9. Teacher scaffolding & 1 & 3.23 \\
\hline Total & 31 & 100.00 \\
\hline
\end{tabular}

\subsubsection{Question 2: What Did You Like When you Participated in the Project?}

The students' responses to question 2 included nine preferred areas based on the frequency and percentage of the analysis of the students' opinions. These areas were: atmosphere, group work, speaking, vocabulary, interaction, 
pronunciation, rehearsal, test and teacher scaffolding. The details of the students' preferences are described in Table 3. Table 3 reveals a total frequency of 31 student preferences for participating in the project. Regarding the highest frequency, the majority of the students (19.35\%) commented that what they liked when they participated in the project was the atmosphere. They had learnt English through retelling Thai folktales in a relaxed atmosphere. Some students reported that they had a lot of fun retelling the stories. The stories were very interesting and the teaching activities were not boring.

One student commented:

"The atmosphere in the classroom was very relaxed and positive, and I had a lot of fun." (FGI2 student 3)

As for the second rank of frequency, several students reported that they liked group work (16.13\%) and speaking activities (16.13\%). Two students commented:

"I liked speaking activities because I had more time to speak English.” (FGI2 student 2)

"I liked working in groups and the way the teacher allowed me to work with new group members." (FGI2 student 5)

Regarding the third rank of frequency, some students felt that they liked working with vocabulary (9.68\%), interacting with friends (9.68\%), pronouncing words (9.68\%), and rehearsal of retelling folktales (9.68\%). Three students commented:

"I liked working with groups members because we could share ideas and learn words together." (FGI 2 student 3)

"I liked the way my friends taught me how to pronounce words." (FGI2 student 5)

"I liked the way we practiced retelling stories or folktales in groups." (FGI2 student 6)

In regard to the lowest frequency rank, few students mentioned that they liked teacher assistance or scaffolding $(3.23 \%)$, as one student reported.

"I liked when the teacher came to my group, sat there and listened to me retelling the stories. If I didn't know how to say some words, he would tell me." (FGI2 student1).

\subsubsection{Question 3: What did you learn from Participating in the Project?}

The students' responses to question 3 included twelve areas of what the students learned, based on the frequency and percentage of the analysis of the students' opinions. The areas in which the students improved contained vocabulary, storytelling skills, pronunciation skills, summary and main idea, interaction, writing skills, reading skills, peer teaching, presentation, grammar, paragraph skills, and memory development. The details of each area are illustrated in Table 4.

Table-4. Students' areas of learning from project participation.

\begin{tabular}{l|c|c}
\hline Areas of learning & Frequency & Percentage \\
\hline 1. Vocabulary & 8 & 17.39 \\
\hline 2. Storytelling skills & 7 & 15.22 \\
\hline 3. Pronunciation skills & 7 & 15.22 \\
\hline 4. Summary and main idea & 7 & 15.22 \\
\hline 5. Interaction & 4 & 8.70 \\
\hline 6. Writing skills & 4 & 8.70 \\
\hline 7. Reading skills & 2 & 4.35 \\
\hline 8. Peer teaching & 2 & 4.35 \\
\hline 9. Presentation & 2 & 4.35 \\
\hline 10. Grammar & 1 & 2.17 \\
\hline 11. Paraphrase skills & 1 & 2.17 \\
\hline 12. Memory development & 1 & 2.17 \\
\hline Total & 46 & 100.00 \\
\hline
\end{tabular}

Table 4 reveals a total number of 46 sub-areas of students' learning from participating in the project. Regarding the highest rank of frequency, the majority of the students reported that they had learnt vocabulary (17.39\%) the most from retelling Thai folktales, as one student commented:

"I had learnt a lot of words and their meanings." (FGI3 student 4).

For the second frequency rank, several students mentioned that they had learnt more about storytelling skills, pronunciation skills, summary and main idea. These areas of improvement account for $15.22 \%$. Some students also commented:

"I learnt how to tell stories and make someone interested in my stories." (FGI3 student 2)

"I had practiced how to pronounce the words ending with /ed/ sound." (FGI3 student 3)

"I knew how to summarize the stories." (FGI3 student 5)

Regarding the third frequency rank, some students $(8.70 \%)$ felt that they had interacted with their peers and they also learnt writing skills, specifically how to write a story summary $(8.70 \%)$. Some students commented:

"I had time to talk to my group members." (FGI3 student 1) 
"When we summarized the stories, we helped to think about words." (FGI3 student 6)

"We had learnt how to write a story summary.” (FGI3 student 3)

In regard to the lowest frequency rank, a few students mentioned that they had learnt more about grammar, paraphrasing, and how to develop their memory telling stories. These areas account for $2.17 \%$.

\subsubsection{Question 4: What do you Want to Improve or Suggest?}

The students' responses to question 4 include two areas regarding activities and materials for learning how to retell stories, based on the frequency and percentage of the student opinion analysis. The details of the students' suggestions are described in Table 5 .

Table-5. Students' suggestions for further improvement.

\begin{tabular}{l|c|c}
\hline Areas of improvement & Frequency & Percentage \\
\hline 1. Activities & 10 & 90.91 \\
\hline 2. Materials & 1 & 9.09 \\
\hline Total & 11 & 100.00 \\
\hline
\end{tabular}

Table 5 reveals a total number of 11 frequencies for further improvements suggested by the students. Regarding the highest rank of frequency, the majority of the students reported that they wanted to have more activities (90.91\%). Some students commented:

"I wanted to have more activities such as doing role play or singing a song after we retold the folktales." (FGI4 student 4)

"I wanted to retell stories using pictures because I can imagine the story pictures." (FGI4 student 6)

"I wanted the teacher to teach me how to retell stories using suitable tones and feeling because the focus of retelling stories is to show the characters' emotions." (FGI4 student 2)

In regard to the material improvement, a few students $(9.09 \%)$ mentioned that they wanted to have more handouts on the tenses and story pictures. One student commented:

"I wanted to have more handouts about tenses." (FGI4 student 5)

\section{Discussion and Conclusion}

One of the major aims of this study was to determine if the application of Task-Based Language Teaching (TBLT) and storytelling has any impact on vocabulary learning in Thai EFL students in conversation and discussion class. The reported findings reveal that the post-test scores were significantly different from the pre-test scores at .05 levels. The current study's findings indicate that participants' significant improvement in vocabulary developments may have resulted from performing narrative tasks that are meaningful to them by providing them frequent opportunities to work with the target language through retelling stories. Repeated meeting of the vocabulary in the stories contributed to vocabulary learning (Nation, 2017). The findings of this study are in line with those of many previous studies in the field of TBLT adopting storytelling. According to Kiernan (2003) narrative tasks are an excellent means of preparing university students for presenting stories in conversation and creating students' identities in the target language. In addition, several studies that adopted storytelling as a means of developing students' vocabulary knowledge assert that storytelling is an effective way for increasing vocabulary learning among EFL students (Abasi \& Soori, 2014; Kuntung, 2007; Phuksuetrong, 2009; Soleimani \& Akbari, 2013; Srihasarn, 2010). The second objective of the present study was to discover the students' opinions towards learning English vocabulary through TBLT and storytelling. The findings of this study reveal that the storytelling tasks helped the students increase their vocabulary knowledge as the tasks of retelling Thai folktales provide the students with more opportunities to learn and practice vocabulary repeatedly with their close group members in a relaxing atmosphere. The students also commented that they had improved their speaking skills, gained more confidence to retell stories in English, and gained better pronunciation skills with words ending in /t/, /d/and /id/ sounds of past tense verbs while retelling stories. These findings are directly in line with previous studies. For example, Kuntung (2007) reported that students agree that using storytelling techniques assisted students in remembering and understanding the meanings of unfamiliar vocabulary. The students also enjoyed studying and were encouraged to gain vocabulary using storytelling. In addition, the findings of Srihasarn (2010) indicate that the students welcomed storytelling and they were encouraged to learn vocabulary through narrative, pleased with their improved intonation, and had fun learning.

It was observed that the EFL students who learnt English vocabulary through TBLT and storytelling had significantly higher vocabulary post-test scores. These findings suggest that the use of Task-Based Language Teaching and storytelling techniques adopting Thai folktales has a notable impact on students' vocabulary knowledge. The current study has provided further empirical evidence for the merits of TBLT and storytelling technique in teaching English in EFL contexts where opportunities for interacting with English are limited. It is also suggested that the incorporation of Task-Based Language Teaching and narrative techniques may be used in the certain language teaching and learning context that aims to improve learners' vocabulary acquisition or other language learning domains. 


\section{Recommendations}

The present study's results indicate that storytelling utilizing folktale language learning tasks could be applied to increase language learners' vocabulary knowledge. The tales chosen should be appropriate for the learners' interests and level of language ability. Multicultural differences should be included into storytelling classes to improve students' intercultural awareness and communication abilities.

\section{References}

Abasi, M., \& Soori, A. (2014). Is storytelling effective in improving the English vocabulary learning among Iranian children in Kindergartens? International Journal of Education and Literacy Studies, 2(3), 7-11. Available at: https://doi.org/10.7575/aiac.ijels.v.2n.3p.7.

Alotaibi, M. G. (2020). The effect of project-based learning model on persuasive writing skills of Saudi EFL secondary school students. English Language Teaching, 13(7), 19-26. Available at: https://doi.org/10.5539/elt.v13n7p19.

Azis, Y. A., \& Hu, S. (2020). Collaborative digital storytelling-based task for EFL writing instruction: Outcomes and perceptions. The Journal of AsiaTEFL, 17(2), 562-579. Available at: https://doi.org/10.18823/asiatefl.2020.17.2.16.562.

Bakar, N. I. A., Noordin, N., \& Razali, A. B. (2019). Improving oral communicative competence in English using project-based learning activities. English Language Teaching, 12(4), 73-84. Available at: https://doi.org/10.5539/elt.v12n4p73.

Bell, S. (2010). Project-based learning for the 21 st century: Skills for the future. The Clearing House: A Journal of Educational Strategies, Issues and Ideas, 83(2), 39-43. Available at: https://doi.org/10.1080/00098650903505415.

Bualuang, C., Sinprajakphol, S., \& Chanphorm, K. (2012). Enhancing English vocabulary learning and ability of retention through the use of CALL. Taksin University Library Journal, 1(1), 92-103.

Deveci, T. (2018). Student perceptions on collaborative writing in a project-based course. Universal Journal of Educational Research, 6(4), 72 1732. Available at: https://doi.org/10.13189/ujer.2018.060415.

Hamamorad, A. (2018). Incorporating task based language learning approach into a Kurdish young EFL learners' classroom through storytelling technique in a basic school in Kurdistan region. European Journal of Multidisciplinary Studies, 3(2), 174-180. Available at: https://doi.org/10.26417/ejms.v7i2.p174-180.

Hamzeh, A. (2016). Investigating the washback effects of task-based instruction on the Iranian EFL learners' vocabulary learning. English Language Teaching, 9(12), 16-21. Available at: https://doi.org/10.5539/elt.v9n12p16.

Hines, M. (1995). Story theater. In English Teaching Forum, 33(1), 6-11.

Khamprated, N. (2012). The problems with the English listening and speaking of students studying at a private vocational school in Bangkok, Thailand. Unpublished Master's Dissertation.

Kiernan, P. (2003). Narrative tasks in communicating language teaching. Paper presented at the Proceedings of the Japan Association for Language Teaching, Shizuoka.

Kuntung, C. (2007). Improving students' vocabulary through storytelling. Khon Kaen: Khon Kaen University.

Liu, X. (2016). Motivation management of project-based learning for business English adult learners. International Journal of higher education, 5(3), 137-145. Available at: https://doi.org/10.5430/ijhe.v5n3p137.

Meri-Yilan, S. (2020). Task-based language learning through digital storytelling in a blended learning environment. Education, 4, $37-43$. Available at: https://doi.org/10.14705/rpnet.2020.42.1085.

Mokhtar, N. H., Halim, M. F. A., \& Kamarulzaman, S. Z. S. (2011). The effectiveness of storytelling in enhancing communicative skills. Procedia-Social and Behavioral Sciences, 18, 163-169. Available at: https://doi.org/10.1016/j.sbspro.2011.05.024.

Nation, P. (2017). How vocabulary is learned. Indonesian JELT: Indonesian Journal of English Language Teaching, 12(1), 1-14. Available at: https://doi.org/10.25170/ijelt.v12i1.1458.

Nunan, D. (2004). Task-based language teaching (1 st ed.). Cambridge: Cambridge University Press.

Phuksuetrong, T. (2009). The use of storytelling to promote students' new vocabulary learning. Mahasarakham: Mahasarakham University.

Samuda, V., \& Bygate, M. (2008). Tasks in second language learning. Basingstoke: Palgrave Macmillan.

Sarani, A., \& Sahebi, L. F. (2012). The impact of task-based approach on vocabulary learning in ESP courses. English Language Teaching, 5(10), 118-128. Available at: https://doi.org/10.5539/elt.v5n10p118.

Sirisrimangkorn, L. (2018). The use of project-based learning focusing on drama to promote speaking skills of EFL learners. Advances in Language and Literary Studies, 9(6), 14-20. Available at: https://doi.org/10.7575/aiac.alls.v.9n.6p.14.

Skehan, P. (2001). Tasks and language performance assessment. In M. Bygate, P. Skehan, छ M. Swain (Eds.), Researching Pedagogic Tasks: Second Language Learning, Teaching and Testing. Harlow: Pearson Education.

Soleimani, H., \& Akbari, M. (2013). The effect of storytelling on children's learning English vocabulary: A case in Iran. International Research Journal of Applied and Basic Sciences, 4(1 1 1), 4005-4014.

Somdee, M., \& Suppasetseree, S. (2013). Developing English speaking skills of Thai undergraduate students by digital storytelling through websites. Paper presented at the 3rd International Conference on Foreign Language Learning and Teaching. Bangkok, Thailand: Language Institute, Thammasat University.

Srihasarn, G. (2010). Using storytelling to facilitate M.1 students' vocabulary learning at Nayomwittayakarn school. Ubon Ratchathani: Ubon Ratchathani University.

Sriwichai, C. (2014). Self-directed learning behaviors in English language learning of Undergraduate Students of University of Phayao. Journal of Humanities and Social Sciences University of Phayao, 2(1),33-41.

Tang, H., Chiou, J.-S., \& Jarsaillon, O. (2015). Efficacy of task-based learning in a Chinese EFL classroom: A case study. English Language Teaching, 8(5), 168-176. Available at: https://doi.org/10.5539/elt.v8n5p168.

Wajnryb, R. (2003). Stories: Narrative activities in the language classroom. Cambridge: Cambridge University Press.

Willis, D., \& Willis, J. (2007). Doing task-based teaching. Oxford: Oxford University Press.

Willis, J. (1996). A framework for task-based learning. Harlow: Longman.

Yegani, H., \& Jodaei, H. (2017). The effect of task-based and topic-based speaking activities on speaking ability of Iranian EFL learners. Online Submission, 5(4), 85-93. 